\title{
Borsa İstanbul'da Yatırımcıların Şirket Yönetimine Katılımını Etkileyen Şirket Düzeyindeki Finansal Faktörler*
}

\author{
Cüneyd Ebrar LEVENT**
}

\section{ÖZET}

Bu çalışmanın amacı, Borsa Istanbul'da şirket düzeyindeki finansal faktörlerin yatırımcıların şirket yönetimine katılmalarına etkisini belirlemektir. Araştırmanın kapsamın 2010-2017 yılları arasında Borsa Ístanbul'da Metal Ana Endeksi ve Metal Eşya Makina Endeksinde yer alan 34 şirket oluşturmaktadır. Araştırmanın amacı doğrultusunda iki ekonometrik model kurulmuş, yöntem olarak panel veri analizi yöntemi seçilmiştir. Panel veri analizi bulguları, halka açıklık oranının artmasının yatırımcıların genel kurula katılımını istatistiksel olarak anlamlı bir şekilde negatif etkilediğini göstermektedir. Araştırmada piyasa değerinin ve genel kurullarda uzaktan katılıma izin veren elektronik genel kurul sisteminin varlığının, hem genel katılımı hem de hakim hissedarlar dışındaki yatırımcıların yönetime katılmalarını pozitif yönde etkilediği bulunmuştur. Aktif kârlılık oranının da yatırımcı katılımına etkisinin bulunduğu, ancak bu etkinin negatif olduğu saptanmıştır. Borç oranı ile yatırımcıların yönetime katılmaları arasında ise istatistiksel bir kanıta ulaşılamamıştır. Benzer şekilde şirketin hisselerinde imtiyazlı payların bulunmasının da yatırımcıların yönetime katılımını etkilemediği bulunmuştur.

Anahtar Kelimeler: Finansal Piyasalar, Borsa İstanbul, Yatırımcı Katılımı, Finansal Faktörler, Panel Veri.

JEL Sinıflandırması: G10, G30, G32, C23.

\section{Company-Level Financial Factors Affecting the Participation of Investors in} Company Management in Borsa Istanbul

\section{ABSTRACT}

The aim of this study is to determine the effect of financial factors at the company-level in Borsa Istanbul on participation of investors in company management. The scope of the study consists of 34 companies which are listed in the Basic Metal Index and Metal Products Machinery Index at Borsa Istanbul between 2010-2017. Two econometric models were established for the purpose of the research and panel data analysis method was chosen. Panel data analysis findings show that the increase in the free float ratio has a statistically significant negative effect on participation of investors in general meetings. In the research, it was found that the market value and the presence of the electronic general meeting system that allowed remote participation in general meetings positively affected both the general participation and the participation of investors other than dominant shareholders in management. Return on assets also had an effect on investor participation, but this effect was found to be negative. No statistical evidence could be reached between the debt ratio and the participation of investors in management. Similarly, it was found that the presence of privileged shares in the company's shares did not affect the participation of investors in company management.

Keywords: Financial Markets, Borsa Istanbul, Investor Participation, Financial Factors, Panel Data.

Jel Classification: G10, G30, G32, C23.

\footnotetext{
* Makale Gönderim Tarihi: 02.01.2020, Makale Kabul Tarihi: 24.02.2020, Makale Türü: Nicel Araştırma ** Dr. Öğr. Üyesi, İstanbul Aydın Üniversitesi Anadolu Bil Meslek Yüksekokulu, cuneydebrarlevent@gmail.com, Orcid ID: 0000-0003-1494-3029.
} 


\section{GíRiş}

Şirketlerin hisse senetlerinin çağrı ve ilan yoluyla halka arz edilerek menkul kıymet borsalarında çok sayıda yatırımcıya satılması, şirketlere sermaye sağlama, likidite ve kredibilitenin artması gibi çeşitli finansal faydalar sunmaktadır. Ayrıca halka kapalı bir şirketin, halka açı bir şirket haline gelmesi, o şirketin kurumsallaşmasına (Kesbiç ve Taşdemir, 2019: 690), yurtiçi ve yurtdışında daha yaygın tanınmasına (Er vd., 2017: 158), ve rakipleri ile rekabet edebilecek kaynaklara ulaşmasına (Pamukçu ve Öztürk, 2018: 24) yardımcı olabilmektedir.

Buna karşın, halka açık hale gelmek, şirketlerin ek yasal yükümlülükler altına girmesine, menkul kıymet borsalarını düzenleyici kurumlar tarafından sürekli izlenmesine ve denetlenmesine neden olmaktadır. Çünkü halka arzın tamamlanıp, hisselerinin borsalarda işlem görmesi sonrasında şirketler, finansal olarak piyasa değeri, hukuksal olarak ise mülkiyet dağılımı (işlem gördüğü süre içinde) anlık olarak değişebilen bir yapıya sahip olmaktadır. Ayırım yapmadan bütün yatırımcıların menfaatlerini korumakla yükümlü olan düzenleyici kurumlar, finansal sistemin istikrarlı ve güvenli bir şekilde işlemesini sağlamak için, halka açık şirketlere diğer anonim şirketlerden farklı ek düzenlemeleri zorunlu kılmaktadır. Bunların başında da tüm pay sahiplerinin yönetim süreçlerine katılımına imkan sağlayabilecek düzenlemeler gelmektedir.

Bu çerçevede halka açık şirketlerde yatırımcılarla sürekli iletişimin sağlanabilmesi için yatırımcı ilişkileri birimlerin kurulması, genel kurul toplantılarının ve gündemlerinin makul bir süre öncesinde yatırımcılara duyurulması, toplantıların tüm pay sahiplerinin katılımına açık olması ve şeffaf bir şekilde gerçekleşmesi gibi kurallar getirilmiştir. Ayrıca aralarında Türkiye'nin de olduğu birçok ülkede yatırımcıların yönetime katılmalarının kolaylaştırılmasının sağlanması için mekanizmalar geliştirilmiş, genel kurul toplantılarının aynı zamanda internet ortamında da yapılması halka açık şirketlere zorunlu kııınmıştır.

Ancak menkul kıymet borsalarında sermayedar olarak yer alan yatırımcıların bir kısmının bütün bu kolaylaştırıcı uygulamalara karşın, şirketin nasıl yönetildiğinden veya yönetileceğinden çok, elde edecekleri değer artı̧̧ kazancı ile ilgilendiği de bir gerçektir. Üstelik bu durum sadece Türkiye gibi gelişmekte olan ülkeler için değil, gelişmiş ülkelerdeki sermaye piyasalarında da yaşanmaktadır (Webb vd., 2003). Kurumsal yatırımcılar başta olmak üzere bazı yatırımcıların ise hisse senedi alım satımlarını uzun vadeli birer "yatırım" olarak gördükleri ve yatırım yaptıkları şirketlerden bilgiler talep ettikleri ve genel kurullara katılım sağladıkları görülmektedir.

Yatırımcıların şirket yönetimlerine katılma istekleri, bireysel amaçları, beklentileri, özellikleri, portföy büyüklükleri gibi davranışsal ve ekonomik faktörlerden etkilenmektedir. Bununla beraber, yatırım yapılan şirketle ilgili finansal faktörlerin de yönetime katılım kararlarına etki etmesi olasıdır. Örneğin piyasa değeri çok yüksek şirketlerin, diğer şirketlere göre daha fazla pay sahibi ile genel kurul toplantıları gerçekleştirdiği gözlenmektedir.

$\mathrm{Bu}$ çalışmanın amacı, Borsa İstanbul'da şirket düzeyindeki finansal faktörlerin yatırımcıların yönetime katılmalarına etkisini belirlemektir. Araştırmanın kapsamını Borsa İstanbul'da Metal Ana Sanayi Endeksi (XMANA) ve Metal Eşya Makina Endeksinde (XMESY) 2010-2017 yılları arasında kesintisiz olarak yer alan 34 şirket oluşturmaktadır. 
Araştırmanın amacı doğrultusunda iki ayrı ekonometrik model kurulmuş, yöntem olarak panel veri analizi yöntemi seçilmiştir. İlk modelde bağımlı değişken genel kurula katılım oranı, ikinci modelde ise yatırımcı katılım katsayısıdır. Şirket düzeyinde finansal faktörleri temsil eden bağımsız değişkenler ise piyasa değeri, fiili dolaşım pay oranı, aktif kârlılık oranı, borç oran1, imtiyazlı hisselerin bulunup bulunmaması ve elektronik genel kurul sisteminin varlığ olarak belirlenmiştir. Tüm veriler Borsa İstanbul (BİST), Kamuyu Aydınlatma Platformu (KAP), Merkezi Kayıt Kuruluşu (MKK) gibi düzenleyici kuruluşlar tarafından yayımlanan halka açık kaynaklardan toplanmıştır.

Yatırımcı katılımı (investor participation) konusu, literatürde çoğunlukla yönetim ve hukuk perspektifinde incelenmiş, son dönemlerde ise davranışsal finans boyutları ile bireysel faktörler ortaya konulmaya çalışılmıştır. Ancak şirket düzeyindeki finansal faktörler yeterince araştırılmamıştır. Ulusal literatürde ise konuyu hem zaman hem de şirket boyutunda ele alan çalışmaya rastlanmamıştır. $\mathrm{Bu}$ açıdan bu çalışmanın literatürdeki önemli bir boşluğu doldurması hedeflenmektedir.

Araştırmanın bu bölümünü takip eden ikinci bölümünde araştırma konusuyla bağlantılı, literatürde yer alan ulusal ve uluslararası çalışmalar sunulmakta, elde edilen bulgular tartışılmaktadır. Ayrıca bu çalışmalara ve teorik yaklaşımlara dayanılarak araştırmada sınanacak hipotezler ortaya konulmaktadır. Üçüncü bölümde ise araştırmanın metodolojisi yer almaktadır. Bu bölümde araştırmanın kapsamı, veri seti, araştırmanın değişkenleri, yöntemi belirtilmekte, araştırmanın ekonometrik modeli açıklanmaktadır. Dördüncü bölümde tanımlayıcı istatistiklere ve korelasyon matrisine yer verildikten sonra durağanlık, çoklu bağlantı, otokorelasyon ve yatay kesit bağımlılığı test sonuçları sunulmaktadır. Daha sonra ise panel veri analiz bulgularına yer verilmektedir. Son bölümde elde edilen sonuçlar tartışılmakta, öneriler ortaya konulmaktadır.

\section{LİTERATÜR İNCELEMESİ VE HIPPOTEZLER}

Halka açık olsun veya olmasın anonim şirketlerde pay sahibi olunması, o payın sahiplerine çeşitli finansal ve yönetsel haklar kazandırmaktadır. Finansal haklar arasında temettü alma hakkı, tasfiye bakiyesine katılma hakkı, yeni pay alma hakkı (rüçhan hakkı) gibi haklar bulunurken, yönetsel haklar arasında şirket faaliyetleri ile ilgili bilgi alma hakkı, oy kullanma hakkı, yönetim kurulunu seçme ve kurula seçilme hakkı yer almaktadır. Kılıç vd. (2014: 77), yönetsel hakların asıl olarak pay sahiplerinin genel kurula katılmaları yoluyla kullanılabileceğini belirterek, şirketin faaliyetlerine, yönetimine ve denetimine tesir etmesi neticesini doğurduğunu belirtmektedir.

Anonim şirketlerde genel kurul, tüm pay sahiplerinin katılma hakkına sahip olduğu, yöneticilerden ve yönetim kurulundan hesap sorabildikleri, yasal olarak yönetime kat1lımın gerçekleşebileceği en üst karar alma organıdır. Strätling (2003: 74-75) genel kurulların üç ana işlevi üzerinde durmuş, bunlardan ilkinin şirketin finansal performansı ve önemli yönetim kararları hakkında hissedarların bilgilendirilmesi, ikincisinin ise genel kurul yetkileri dahilindeki kararlar için pay sahiplerinin izninin alınması olarak belirtmiştir. Yazara göre üçüncü işlev ise genel kurulun yöneticiler ve hissedarlar arasındaki tartışmaların yapılacağı bir "forum" olmasıdır. Dimitrov ve Jain (2011: 1194) ise yıllık genel kurul toplantılarının, hissedarların şirket performansıyla ilgili endişelerini dile getirmelerine ve kurumsal reform için baskı yönetimine imkan sağladığını belirtmiştir. Bütün bu yönleriyle genel kurulun 
hissedarların yönetime (yönetim kararlarına) katılım sağladığı bir ortam olduğunu söylemek mümkündür.

Karasu (2016) anonim şirketlerde küçük hissedarların şirket yönetimine etki etme olanağınının fazla olmadığını belirterek, bu hissedarların şirkete yabancılaştığını ve yönetime ilgisiz kaldığını belirtmektedir. Ancak, azınlık hissedarların korunma derecesi, bu hissedarların hakim ortaklardan hesap sorabilme haklarını kullanmasına (genel kurul kararlarına karşı iptal davası açma gibi) bağlı olmaktadır (Kandemir, 2019). Benzer şekilde genel kurulda alınması gereken önemli nitelikteki işlemler ile ilgili kararlara muhalif kalan hissedarlara, Türkiye uygulamasında ortaklıktan ayrılma hakkı verilmektedir (Vanlı, 2015). Bütün bunlar azınlık dahil hissedarların genel kurula katılmaları ile gerçekleşebilmektedir.

Halka açıklık oranı, genel kurul katılımını etkilemesi mümkün, önemli bir faktör olarak dikkate alınmalıdır. Borsada işlem gören şirketlerin halka açıklık oranının yüksekliği sermayenin çok sayıda hissedara dağılmış olduğunu gösterir ki, bu durumun performansa etkisi birçok araştırmaya konu olmuştur. Bayrakdaroğlu (2010) Borsa İstanbul'da 2005-2009 dönemini kapsayan çalışmasında mülkiyet yoğunluğu değişkenlerinin ve halka açıklık oranının firmaların finansal performansları üzerine etkisi olduğunu saptamıştır. Türkiye’de yapılan bazı çalışmalarda halka açıklık oranı yerine fiili dolaşımdaki pay oranı kullanılmaktadır. $\mathrm{Bu}$ oran, mülkiyet yapısındaki günlük değişimleri dikkate alarak hesaplanmaktadır. Çalışkan ve Kerestecioğlu (2013), BİST'de işlem gören firmaların fiili dolaşımdaki pay oranlarının piyasa performanslarına etkisini incelediği çalışmasında fiili dolaşımdaki pay oranları ile hisse senedi getiri performansı arasında ilişki bulamamasına karşın, işlem hacmi ile anlamlı ve pozitif ilişki saptamıştır. Yatırımcılar doğal olarak şirketlerin finansal performansı ve/veya getiri performansı ile ilgilenmektedir. Bu durumun şirket yönetimine katılımı etkilemesi olasıdır. Bu etkinin mümkün olduğunu savunan Yılmaz (2017), şirketlerde halka açıklık oranının artmasının, yatırımcıların genel kurul toplantılarına katılımını azaltabileceğini ve bunun da şirketin azınlığın hakimiyetine girmesine neden olacağını belirtmiştir.

Piyasa değeri, yatırımcıların şirketin yönetimine katılma isteklerini etkilemesi muhtemel diğer bir faktördür. Literatürde piyasa değeri yüksek firmaların yatırımcılarına daha fazla kazanç sunduğu konusunda farklı sonuçlara ulaşılmaktadır. Ancak genel olarak bakıldığında, piyasa değeri yüksek firmaların piyasa değeri düşük firmalara göre daha yüksek işlem hacmine sahip oldukları (James ve Edmister, 1983), dolayısıyla daha fazla yatırımcıyı çektikleri görülmektedir. Piyasa değerinin yüksekliği, bir şirketin iyi yönetildiği ve daha iyi finansal performans gösterdiği anlamına gelmemekle birlikte, literatürde özellikle gelişmekte olan ülkelerde, kurumsal yönetim-piyasa değeri arasında pozitif ve anlamlı korelasyon bulan çalışmalar bulunmaktadır (Black, 2001; Ararat vd., 2017). Bu doğrultuda yapılan bir diğer çalışmada Balasubramanian vd. (2010), Hindistan'da firma piyasa değeri ile genel kurumsal yönetim endeksi arasında pozitif bir ilişkinin yanı sıra hissedar haklarını kapsayan bir alt endeksin kesitsel kanıtlarını da bulduğunu belirtmiştir. Buradan hareketle yatırımcı ve diğer paydaşların haklarının dikkate alınmasının piyasa değeri ile ilişkisinin olabileceği, bunun da yatırımcıların bu şirketlerin yönetimlerine katılmalarını etkilemesinin söz konusu olabileceği söylenebilir.

Bu konuda incelenmesi gereken bir diğer faktör de kârlılıktır. Kârlılığın yatırımcı katılımına etkisi, o şirket hisselerini elinde bulunduran yatırımcı türleri ile ilgili olduğu 
söylenebilir. Kandemir (2019) şirket yönetimi ile ilgilenmeyen, temettüye önem veren hissedarları "kâr odaklı yatırımcı" olarak nitelendirerek, bu tip yatırımcıların şirketin temettü dağıtma politikasından memnun olmama durumlarında bile şirket yönetimine müdahale etmek yerine, hisselerini satmayı tercih edeceklerini belirtmektedir. İngiltere'deki yatırımc1 katılımın inceleyen Webb vd. (2003) ise memnun olmayan yatırımciların hisse satmak dışındaki diğer bir alternatifinin yıllık genel kurul toplatılarına katılarak şirket stratejisini etkilemede etkin rol oynayabilecekleri olduğunu vurgulamıştır. Tekten (2018) ise yatırımcıların halka açık şirketlerin işleyişlerinden daha çok, elde edecekleri temettü ile ilgilendiklerini belirterek, bunun genel kurul toplantılarına olan ilgiyi azalttığını belirtmektedir. Aytekin ve İbiş (2014) Borsa İstanbul'da işlem gören firmaların mülkiyet yapıları ile finansal performansları ilişkisini araştırmıştır. Yazarlar, genel olarak mülkiyet yapısı değişkenlerinin firmaların finansal performanslarını etkilediğini belirterek, en büyük ortağın payının hem aktif kârlılık hem de özsermaye kârlılığını etkilediği sonucuna ulaşmıştır.

Halka açık şirketlerin borç oranları da yatııımcı kararlarını etkilemesi muhtemel finansal faktörlerden biridir. Yüksek faizli borçlanma, şirketleri orta ve uzun vadede finansman maliyetlerinin yükselmesi sorunuyla karşı karşıya bırakabilmektedir, bu da kârlılı̆ı olumsuz etkilemektedir. Bununla beraber, varlık finansmanında yabancı kaynak kullanılması, kaldıraç etkisi meydana getireceğinden şirketlerin kârlılığını arttırması da söz konusudur (Topal, 2006: 67). Akpınar (2016) BİST'de 2010-2013 yılları arasında BİST100 endeksinde yer alan ve finans sektörü dışındaki 81 firmayı kapsayan araştırmasında sermaye yapısının firma performansına etkisini araştırmıştır. Yazar, kısa vadeli borç oranının özkaynak kârlılığına negatif yönlü etki yaptığı sonucuna ulaşırken, uzun vadeli borç oranı ve toplam borç oranının anlamlı bir etkisini saptayamamıştır.

Anonim şirketlerde sermayeyi oluşturan bazı paylara, diğer paylara nazaran belirli ayrıcalıklar, üstünlükler veya özel haklar tanınabilmektedir. Bu durum genel olarak imtiyaz olarak adlandırılmaktadır. Paylara tanınan imtiyazlar, kâr dağıtımında imtiyaz, tasfiye bakiyesine iştirakte imtiyaz veya oy hakkı gibi diğer hususlarda imtiyaz şeklinde olabilmektedir (Ünal, 2000; Çalal, 2017). OECD Kurumsal Yönetim İlkeleri, imtiyazlı hisselere karşı çıkmamakla beraber, aynı imtiyaza sahip hisselere eşit muamele yapılmasını önermektedir (OECD, 2004). Borsa İstanbul'da işlem gören bazı şirketlerde oy hakkındaki imtiyazın, yönetim kuruluna aday gösterme imtiyazı şeklinde tanındığı da görülmektedir. $\mathrm{Bu}$ durum, azınlıktaki yatırımcılarda genel kurula katılmaları durumunda bile, etkinliklerinin olmayacağı algısına sebep olabilecektir.

Hakim hissedarlar dışındaki yatırımcıların genel kurullara, dolaysıyla yönetime katılımlarının sağlanması için, düzenleyici kurumlar tarafından geçmişte alınan tedbirler yeterince başarılı olamamıştır. Genel kurullara katılımı kolaylaştırmak aynı zamanda oluşan güç boşluğunu kısmen gidermek için, internet üzerinden uzaktan katılımın sağlanması önem kazanmaktadır (Pulaşlı, 2011). Yatırımcıların şirket yönetime elektronik ortamda katılımlarını sağlanması ile ilgili tartı̧malar, internet yoluyla gerçekleşen hisse senedi alım satım işlemlerinin yoğunlaşmasından sonra hızlanmıştır. Lattemann (2005), kurumsal yönetim bağlamındaki en büyük sorunlardan birinin, şeffaflık derecesini ve bilgi asimetrisini etkileyen yönetim ve yatırımcılar arasındaki vekalet ilişkisinden kaynaklandığını belirterek, elektronik sistemlerin doğrudan etkileşim sağlayarak bilgi asimetrisinin azaltılmasına ve şeffaflı̆̆ın artırılmasına yardımcı olacağını belirtmiştir. Uygulamada birçok ülke, mevzuatlarında gerekli düzenlemeleri yaparak, aynı anda hem fiziksel hem online genel kurul (hybrid annual general 
meeting) veya sadece sanal genel kurul (virtual-only annual general meeting) sistemlerini hayata geçirmişlerdir. Türkiye'de de 2012'de yürürlüğe giren, 13.01.2011 tarihli 6102 sayılı Türk Ticaret Kanunu ile "elektronik genel kurul" mevzuata girmiş (TTK, 2011) ve ikincil düzenlemelerle halka açık şirketlerin genel kurullarını elektronik ortamda da yapmaları zorunlu kılınmıştır. Böylece hissedarların yönetim kararlarına daha fazla dahil olmalarının önü açılmıştır.

Elektronik genel kurul sisteminin (EGKS) yatırımcı katılımına etkisi konusunda literatürde çok az çalışma bulunmaktadır. Bunlardan Gao vd. (2019) Çin Borsasını ele alan çalışmasında, online genel kurul sisteminin hissedar katılımını önemli oranda arttırdığını belirtmiştir. Yazarlar, online genel kurul sistemine sahip firmaların olmayanlara göre \%35 daha fazla azınlık hissedar katılımı sağladığını saptamışlardır. Türkiye'de ise Karayel ve Koçak (2015) Türkiye'de EGKS'ye geçilmesinden sonra, sistemin işleyişi ve geleceği ile ilgili hususları, halka açık şirketlerin EGKS'den sorumlu yöneticilerine sorarak bu kapsamda bir anket çalışması yapmıştır. Yazarlar, yöneticilerin çoğunluğunun sistemi pay sahiplerinin katılımını arttıran bir uygulama olarak değerlendirdiklerini belirtmişlerdir. Borsa İstanbul'a yönelik diğer bir çalışmada ise Levent (2018: 100), elektronik genel kurul sisteminin BİST-30 endeksindeki şirketlerde genel kurullara katılımı arttırdığını bulmuştur. Buradan hareketle elektronik genel kurul sisteminin varlığının yatırımcıların şirketlerin yönetimlerine katılmalarını etkilemesinin mümkün olabileceği söylenebilir.

Yukarıda belirtilen, literatürde yer alan çalışmalardan yola çıkılarak, bu araştırmada aşağıdaki hipotezlerin geçerliliği araştırılacaktır:

H1: Şirketin fiili dolaşım pay oranı, hissedarların şirket yönetimine katılımını etkilemektedir.

H2: Şirketin piyasa değeri, hissedarların şirket yönetimine katılımını etkilemektedir.

H3: Şirketin kârlılığı (aktif kârlılı̆̆ı), hissedarların şirket yönetimine katılımını etkilemektedir.

H4: Şirketin borç oranı, hissedarların şirket yönetimine katılımını etkilemektedir.

H5: Şirketin hisselerinde imtiyazlar bulunması, hissedarların şirket yönetimine katılımını etkilemektedir.

H6: Genel kurullarda uzaktan katılıma izin veren elektronik genel kurul sisteminin varlığı, hissedarların şirket yönetimine katılımını etkilemektedir.

H7: Şirketin piyasa değeri, hakim ortaklar dışındaki yatırımcıların şirket yönetimine katılımını etkilemektedir.

H8: Şirketin kârlılı̆̆ (aktif kârlılık), hakim ortaklar dışındaki yatırımcıların şirket yönetimine katılımını etkilemektedir.

H9: Şirketin borç oranı, hakim ortaklar dışındaki yatırımcıların şirket yönetimine katılımını etkilemektedir. 
H10: Şirketin hisselerinde imtiyazlar bulunması, hakim ortaklar dışındaki yatırımcıların şirket yönetimine katılımını etkilemektedir.

H11: Genel kurullarda uzaktan katılıma izin veren elektronik genel kurul sisteminin varlığı, hakim ortaklar dışındaki yatırımcıların şirket yönetimine katılımını etkilemektedir.

\section{ARAŞTIRMANIN VERİ VE YÖNTEMİ}

\subsection{Araştırmanın Amaç ve Kapsamı}

$\mathrm{Bu}$ araştırmada Borsa İstanbul'da (BİST) işlem gören halka açık şirketler düzeyindeki finansal faktörlerin yatırımcıların şirket yönetimine katılımına etkisinin belirlenmesi amaçlanmaktadır. Yatırımcıların yönetime katılmalarında bireysel faktörlerin etkisi (portföy büyüklüğ̈̈, yatırım amaçları, imkanları vb.) önemli bir faktördür. Bununla birlikte, şirketle ilgili unsurların özellikle finansal faktörlerin de katılıma etkisi bulunmaktadır. "Neden bazı şirketlerin genel kurul toplantıları sadece birkaç hakim hissedarla yapıllırken, bazı şirketler toplantılarını yüzlerce yatırımcı ile gerçekleştirmektedir?" Bu çalışma finansal bakış açısıyla bu sorunun cevabını ampirik analizle ortayı koymayı amaçlamaktadır.

Araştırma, Borsa İstanbul'da Metal Ana Sanayi Endeksi (XMANA) ve Metal Eşya Makina Endeksinde (XMESY) 2010-2017 yılları arasında kesintisiz olarak yer alan şirketleri kapsamaktadır. Araştırmada Metal Ana Sanayi ve Metal Eşya Makina sektörlerinin seçilmesinde, üç temel neden bulunmaktadır. Bunlardan ilki bu sektörlerin Türkiye ekonomisine yaptığı katkı ve demir, çelik, makina ve beyaz eşya gibi ürettiği ürünlerle Borsa İstanbul'da yer alan diğer sektörleri etkileme potansiyelinin bulunmasıdır. İkinci neden ise bu sektörlerdeki firmaların piyasa değeri ve toplam varlıklar açısından birbirlerinden önemli farklılıklara sahip olmasıdır. Son olarak bu firmaların mülkiyet yapılarının ve yatırımcı profillerinin değişkenliğidir. Araştırma kapsamında Arçelik, Ereğli Demir Çelik, Otokar ve Tofaş Oto Fabrikası gibi piyasa değeri ve yabancı takas oranı yüksek firmaların yanı sıra piyasa değeri düşük ve daha çok yerli yatırımcıların ilgi gösterdiği firmalar da bulunmaktadır. Bu bağlamda seçilen sektörlerin, BİST 30 veya BİST 50 endekslerine göre, Borsa İstanbul'un genelini daha iyi temsil edeceği düşünülmektedir. Söz konusu dönem içerisinde XMANA ve XMESY endekslerinde toplam 35 şirket yer almaktadır. Bu şirketlerin bir tanesinde 2016 faaliyet dönemine ilişkin yıllık olağan genel kurul toplantısı 2017 faaliyet dönemi ile birleştirilerek beraber yapıldığı için, bu yıllara ait ayrı ayrı katılım oranı verileri tespit edilememiştir. Bu yüzden bu şirket araştırma kapsamından çıkarılarak analizler 34 şirket ile gerçekleştirilmiştir.

\subsection{Veri Seti}

Araştırmada halka açık şirketler düzeyindeki finansal faktörlerin yatırımcıların şirket yönetimine katılımına etkisi zaman boyutu ile de incelenmektedir. Araştırma kapsamındaki 34 şirkete ait gerekli tüm veriler toplanmıştır. Bu sebepten dolayı veri seti, yatay kesit ve zamanı dikkate alan dengeli panel veri seti (balanced panel data set) olarak oluşturulmuştur.

Tüm ham veriler Borsa İstanbul (BİST), Kamuyu Aydınlatma Platformu (KAP), Merkezi Kayıt Kuruluşu (MKK) gibi düzenleyici kuruluşlar tarafindan yayımlanan halka açık kaynaklardan elde edilmiştir. 
Şirketlerin genel kurul katılım oranları için ilk önce şirketlerin hangi yıl hangi tarihte olağan genel kurul yaptıkları tespit edilmiş, daha sonra ilgili imzalı genel kurul tutanakları ve imzalı hazirun cetvelleri toplanmış ve bunlar analiz edilerek gerekli oranlar hesaplanmıştır. Şirketlerin halka açıklığına ilişkin verilerde ise, bir sonraki bölümde gerekçeleri açıklandığı şekilde MKK tarafından yayımlanan fiili dolaşımdaki pay oranları kullanılmıştır.

Borç oranı, aktif kârlılık oranı gibi finansal veriler, şirketlerin KAP'a bildirdikleri finansal tablolardan yararlanarak ilgili genel kurulda oya sunulan dönem sonu dikkate alınarak (Örneğin 2010 olağan genel kurulu 2011'de yapılmasına karşın, genel kurulda 2010 faaliyetleri tartışılmaktadır) hesaplanmıştır. Piyasa değeri hesaplanmasında da aynı metodoloji takip edilmiştir. Şirket hisselerinde imtiyazlı payların olup olmadığ 1 ise, hem şirketlerin faaliyet raporlarından hem finansal tablo dipnotlarından hem de KAP'a yapılan bildirimlerden kontrol edilmiştir. Elektronik genel kurul sisteminin varlığı ile bilgilere ise yine KAP sitesindeki genel kurul tutanaklarından ulaşılmıştır.

\subsection{Araştırmanın Yöntem ve Modeli}

Yatırımcıların, yatırım yaptıkları şirket yönetimine katılım oranları ve bunları etkileyen finansal faktörler, hem şirketler arasında farklılık gösterdiği için hem de şirketlerin kendi içlerinde incelenen zaman döneminde değişebildiği için panel veri analiz yöntemi ile analiz edilmektedir. Panel analizi genel olarak daha bilgilendirici veriler, daha fazla değişkenlik, değişkenler arasında daha az doğrusallık, daha fazla serbestlik derecesi ve daha fazla verim sağlamaktadır (Baltagi, 2005: 5). Bunun yanında panel veri analizi, yatay kesit birimlerin farklı eğilim ve davranışlara sahip olmasını dikkate alarak, bu farklılıkların model içindeki kontrolüne ve ölçülebilmesine izin vermektedir (Tarı, 2014: 476).

Araştırmada şirket düzeyindeki finansal faktörlerin, yatırımcıların yönetime katılımlarına etkisi aşağıdaki belirtilen iki ekonometrik modelle araştırılmaktadır:

Model 1:

$K T O_{\text {it }}=\beta_{0}+\beta_{1} F D P O_{\text {it }}+\beta_{2} P I Y D_{\text {it }}+\beta_{2} A K O_{\text {it }}+\beta_{4} B O R C_{\text {it }}+\beta_{5} I M T_{\text {it }}+\beta_{6} E G K S_{\text {it }}+\varepsilon_{\text {it }}$

Model 2:

$Y T K K_{\text {it }}=\beta_{0}+\beta_{1} P I Y D_{\text {it }}+\beta_{2} A K O_{\text {it }}+\beta_{\text {a }} B O R C_{\text {it }}+\beta_{4} I M T_{\text {it }}+\beta_{5} E G K S_{\text {it }}+\varepsilon_{\text {it }}$

Modellerde i yatay kesit (şirket), $\mathrm{t}$ ise zaman boyutunu temsil etmektedir. İlk modelde bağımlı değişken genel kurula katılım oranı, ikinci modelde ise yatırımcı katılım katsayısıdır. Şirket düzeyinde finansal faktörleri temsil eden bağımsız değişkenler ise piyasa değeri, fiili dolaşım pay oranı, aktif kârlılık oranı, borç oranı, imtiyazlı hisselerin bulunup bulunmaması ve elektronik genel kurul sisteminin varlığ olarak belirlenmiştir. Bu iki modelde yer alan değişkenler aşağıda açıklanmaktadır: 
Katılım Oranı (KTO): Literatür bölümünde de açıklandığı gibi halka açık şirketlerde yatırımcıların yönetime katılmaları, alınacak kararlarda görüşlerini belirtmeleri, oy kullanmaları, aday olmaları veya mevcut adaylarından birini seçmeleri, genel kurul toplantılarına katılmaları ile mümkün olmaktadır. Bu yüzden Katılım Oranı (KTO) Model 1 için bağımlı değişken olarak seçilmiş̧tir. KTO aşağıdaki formülle (3) hesaplanmaktadır:

$$
\text { KTO }=\frac{\text { Genel Kurul Toplantısına Katılan Yatırımcıların Hisse Adeti Toplamı }}{\text { Şirketin Toplam Hisse Adeti }}
$$

(3) numaralı eşitlikte pay kısmında yer alan verilerin elde edilmesi için her şirketin araştırma kapsamındaki 8 yıl boyunca yaptığı olağan genel kurul toplantı tutanakları ve imzalı hazirun cetvellerine ulaşılmıştır. Buradan kurula katılan yatırımcıların hisse adetleri toplamı elde edilmiş, bu sayı şirketin toplam hisse adetine bölünerek KTO değişkeni elde edilmiştir.

Fiili Dolaşımdaki Pay Oranı (FDPO): Fiili dolaşımdaki pay oranı (FDPO), Sermaye Piyasası Kurulu (SPK) tarafindan, Borsa İstanbul'da işlem gören payların halka açıklık oranlarını gösteren bir kavram olarak tanımlanmış olup, MKK tarafindan hesaplanarak ilan edilmektedir (BIST, 2018). Araştırmada halka açıklık oranı yerine, özellikle FDPO kullanılmasının iki temel sebebi vardır. Bunlardan ilki, halka açıklık oranının genellikle birincil ve ikincil halk arz sonrası sunulan hisseleri ifade etmesinden dolayı gerçek mülkiyet durumunu her zaman yansıtmamasıdır. İkinci sebep ise, şirketlerin kendilerinin veya hakim ortakların, borsa yoluyla şirket hisselerini alıp satabilmesi, böylece dolaşımdaki payların değişiyor olmasıdır. Bu yüzden, bu araştırmada Çalışkan ve Kerestecioğlu (2013) tarafindan yapılan araştırmada olduğu gibi, MKK tarafindan düzenli olarak ilan edilen FDPO verileri kullanılmıştır. FDPO günlük olarak değişkenlik gösterebildiği için olağan genel kurul toplantısından bir gün önceki FDPO esas alınmıştır.

Yatırımeı Katılım Katsayısı (YTKK): Hisse senedi alarak şirketlere ortak olan yatırımcıların bir kısmı (özellikle hakim ortaklar dışındaki küçük yatırımcılar) literatür bölümünde de anlatıldığı gibi şirketlere yabancılaşmakta, yönetime katılmayı tercih etmemektedir. Buna karşın hakim hissedarlar veya fiili dolaşım pay oranı dışında kalan hissedarlar ise çoğunlukla genel kurul toplantılarına iştirak etmekte (Gao vd., 2019), çıkmasını istedikleri kararlar lehine oy kullanmaktadır. Buradan hareketle bu araştırmada hakim hissedarlar haricindeki yatırımcıların yönetime katılımını ölçmek için yatırımcı katılım katsayısı (YTKK) önerilmekte ve aşağıdaki formülle (4) hesaplanmaktadır.

$$
\text { YTKK }=\left(\frac{\text { Genel Kurul Toplantısına Katılan Yatırımcıların Pay Toplamı + Fiili Dolaşımdaki Pay Adet }}{\text { Șirketin Toplam Pay Adeti }}\right.
$$

Yatırımeı katılım katsayısının sıfirdan büyük olması, hakim hissedarlar dışında ortakların da genel kurula katılım gösterdiğini ifade etmektedir. Sıfirdan küçük olması ise hakim hissedarların bir kısmının katılım sağlamadığına işaret etmektedir. YTKK'nin sıfır olması ise hakim hissedarlar dışında yönetime katılım olmadığını göstermektedir. Örneğin 
fiili dolaşım pay oranı $\% 20$ bir şirkette, fiili dolaşımda olmayan hisselerin oranı $\% 80$ olmaktadır. Hakim hissedarların, aile üyelerinin veya imtiyazlı ortakların tamamının genel kurula katıldığı, dışarıdan katılımın olmadığ 1 bir durumda YTKK, sıfıra eşit olmaktadır. YTKK, bu araştırmada Model 2'de bağımlı değişken olarak yer almakta olup, hesaplanmada kullanılan veriler KAP ve MKK resmi sitelerinden alınmıştır.

Piyasa Değeri (PIYD): Piyasa değeri olarak Borsa İstanbul'un tanımı esas alınmıştır. Buna göre piyasa değeri "sermayeyi temsil eden toplam pay sayısının pay fiyatı ile çarpılması suretiyle hesaplanır" (BİST, 2018). Araştırmada şirketlerin piyasa değeri, literatürdeki birçok araştırmaya uygun olarak (Agarwal vd., 2008; Wang vd., 2011) doğal logaritması (ln) alınarak kullanılmaktadır. PIYD değişkeni, LNPIYD olarak her iki modelde de bağımsız değişken olarak yer almaktadır.

Aktif Kârlılık Oranı (AKO): Aktif kârlılık oranı, şirket kârlılığın bir göstergesi olarak Model 1 ve Model 2'de bağımsız değişken olarak kullanılmakta, net kârın toplam varlıklara bölünmesi ile hesaplanmaktadır.

Borç Oranı (BORC): Borç oranı, şirketin sermaye yapısının bir göstergesi olarak her iki modelde de bağımsız değişken olarak yer almakta, bilançodaki kısa ve uzun vadeli borçların toplamının, toplam kaynaklara bölünmesi ile hesaplanmaktadır.

Paylarda İmtiyazların Varlığı (IMT): Bazı şirketlerin bir kısım payları, diğer paylara göre çeşitli imtiyazlar içermektedir. IMT değişkeni her iki modelde bağımsız, ikili değişken (binary variable) olarak yer almaktadır. İlgili şirketin paylarında incelenen yılda imtiyaz bulunuyorsa (bazı şirketlerin paylarındaki mevcut imtiyazlar genel kurul kararı ile kaldırılabilmektedir) 1 değerini, bulunmuyorsa 0 değerini almaktadır.

Elektronik Genel Kurul Sisteminin Varlığı (EGKS): Türkiye'de düzenlemelerde de yer alan elektronik genel kurul sistemi (EGKS) Ekim 2012'den sonraki genel kurullarda uygulanmaya başlanmıştır. Bu araştırmada EGKS değişkeni her iki modelde de bağımsız, ikili değişken (binary variable) olarak yer almaktadır. İlgili şirketin incelenen yılında sistem uygulanmışsa 1 , uygulanmamışsa 0 değerini almaktadır.

Yukarıda bağımlı ve bağımsız değişkenleri tanıtılan, (1) ve (2) numaralı denklemlerde belirtilen modeller, panel veri analiz yöntemi ile analiz edilmektedir. Analize geçilmeden panel veri analizi ve varsayımları ile ilgili gerekli testler yapılacaktır. Bu doğrultuda durağanlık, çoklu doğrusal bağlantı, otokorelasyon, yatay kesit bağımlılığı gibi testler uygulanacaktır. Daha sonra panel veri model belirleme testleri yapılacaktır. Gerek bu testler gerekse analizler için STATA 14 ve EVIEWS 9 programları kullanılmıştır. Bir sonraki bölümde araştırmada elde edilen ampirik bulgulara yer verilmektedir.

\section{AMPÍRİK BULGULAR VE YORUM}

Araştırma kapsamındaki 34 şirketin 8 yıllık verilerine ait tanımlayıcı istatistikler Tablo 1 'de sunulmaktadır. Katılma oranının (KTO) \%21,04 ile \%97,05 arasında dağıldığı ve \%69,02 ortalamaya sahip olduğu görülmektedir. Yatırımcı katılım katsayısının ortalamasının \%1,24 bulunması ise, hakim ortaklar dışındaki yatırımcıların genel kurullara ve yönetime katılmaya fazla istekli olmadığına işaret etmektedir. Fiili dolaşım pay oranı (FDPO) ortalaması \%32,25 
olarak tespit edilmiş olup, bu sonuç araştırma kapsamındaki şirketlerin üçte ikisinden fazlasının büyük ortaklar tarafindan kontrol edildiğini göstermektedir. Aktif kârlılık oranı (AKO) ortalaması $\% 4,68$, borç oranı (BORC) ortalaması $\% 55,70$ olarak bulunmuştur. IMT ortalamasının 0,50 çıkması ise, araştırma kapsamındaki şirketlerin hisselerinin yarısında imtiyazlı paylar bulunduğunu göstermektedir.

Tablo 1. Bağımlı ve Bağımsız Değişkenlere Ait Tanımlayıcı İstatistikler

\begin{tabular}{lrrrrr}
\hline Değişkenler & $\begin{array}{r}\text { N } \\
\text { (Gözlem Sayısı) }\end{array}$ & Ortalama & Minimum & Maksimum & Standart Sapma \\
\hline KTO & 272 & 0.6902 & 0.2104 & 0.9705 & 0.1886 \\
YTKK & 272 & 0.0124 & -0.2910 & 0.5741 & 0.1122 \\
FDPO & 272 & 0.3222 & 0.0534 & 0.8255 & 0.1831 \\
LNPIYD & 272 & 19.5195 & 15.8030 & 24.2806 & 1.8208 \\
AKO & 272 & 0.0468 & -0.2856 & 0.4356 & 0.0964 \\
BORC & 272 & 0.5570 & 0.0531 & 1.7075 & 0.2332 \\
IMT & 272 & 0.5000 & 0.0000 & 1.0000 & 0.5009 \\
EGKS & 272 & 0.7500 & 0.0000 & 1.0000 & 0.4338 \\
\hline
\end{tabular}

Tablo 2'de ise bağımlı ve bağımsız değişkenlere ilişkin korelasyon matrisi sunulmaktadır. Model 1'de incelenen bağımlı değişken KTO ile bağımsız değişken FDPO arasında çok kuvvetli ve ters yönlü korelasyonun olduğu görülmektedir. Bu durum, fiili dolaşım pay oranının artmasının genel kurula katılımı azalttığına yönelik teorik yaklaşımları desteklemektedir. Bağımsız değişkenlerin kendi aralarındaki korelasyonları incelendiğinde LNPIYD-FDPO, AKO-FDPO, LNPIYD-AKO, LNPIYD-IMT, AKO-BORC ve AKO-IMT değişkenleri arasında \%1 düzeyinde anlamlı ilişkiler bulunmaktadır. Bunun, panel veri analiz modellerinde probleme sebep olup olmayacağı Tablo 4'te verilen çoklu doğrusal bağlantı testlerinde incelenecektir.

Tablo 2. Korelasyon Matrisi

\begin{tabular}{lrrrrrrrr}
\hline Değişkenler & KTO & YTKK & FDPO & LNPIYD & AKO & BORC & IMT & EGKS \\
\hline KTO & 1.000 & & & & & & & \\
\hline YTKK & $0.346^{*}$ & 1.000 & & & & & & \\
\hline FDPO & $-0.818^{*}$ & $0.256^{*}$ & 1.000 & & & & & \\
\hline LNPIYD & $0.546^{*}$ & $0.234^{*}$ & $-0.419^{*}$ & 1.000 & & & & \\
\hline AKO & $0.243^{*}$ & 0.018 & $-0.239^{*}$ & $0.321^{*}$ & 1.000 & & & \\
\hline BORC & 0.072 & 0.155 & 0.021 & 0.033 & $-0.510^{*}$ & 1.000 & & \\
\hline IMT & 0.045 & 0.088 & 0.007 & $0.314^{*}$ & $0.349^{*}$ & -0.085 & 1.000 & \\
\hline EGKS & 0.122 & $0.225^{*}$ & 0.012 & 0.113 & 0.075 & 0.039 & 0.000 & 1.000 \\
\hline
\end{tabular}

*\% 1 düzeyinde istatistiksel olarak anlamlı 
Bir zaman serisi modeli geliştirildiğinde, stokastik sürecin niteliği zamanla değiş̧iyorsa, yani seri durağan değilse, serinin geçmiş ve gelecek yapısının basit bir cebirsel modelle ifade edilmesi imkansızdır (Kutlar, 2012: 417). Bu yüzden panel veri analizine geçmeden önce serilerin durağanlılığının test edilmesi gerekmektedir. Bu araştırmada modellerde yer alan serilerin durağanlığı Levin, Lin ve Chu (2002) tarafindan geliştirilen birim kök testi ile araştırılmakta olup sonuçlar Tablo 3'te verilmektedir. Bu testin sıfir hipotezi ve alternatif hipotezi aşağıda verilmektedir (Tatoğlu, 2018: 68):

Ho: Paneller birim kök içermektedir.

$\mathrm{H}_{1}$ : Paneller durağandır.

Tablo 3. Panel Birim Kök Testi Sonuçları

\begin{tabular}{lcr}
\hline \multicolumn{3}{c}{ Levin, Lin, Chu t Testi } \\
\hline Değişkenler & İstatistik Değeri & Olasılık Değeri (p) \\
\hline KTO & -240.35 & $0.0000^{*}$ \\
FDPO & -253.44 & $0.0000^{*}$ \\
YTKK & -13.56 & $0.0000^{*}$ \\
LNPIYD & -9.44 & $0.0000^{*}$ \\
AKO & -9.40 & $0.0000^{*}$ \\
BORC & -12.78 & $0.0000^{*}$ \\
\hline
\end{tabular}

* \% 1 düzeyinde istatistiksel olarak anlamlı

Tablo 3'te yer alan serilerin tamaminda $\mathrm{H}_{0}$ hipotezi reddedilmektedir, bu ise serilerin durağan olduğu anlamına gelmektedir. Bu sebeple herhangi bir dönüşüm veya fark alma işlemine gerek bulunmamaktadır.

Çoklu doğrusallık (multicollinearity), regresyon modelindeki iki veya daha fazla bağımsız değişkenin yüksek derecede ilişkili olduğu ve bağımlı değişken üzerindeki bireysel etkilerinin izole edilmesini zorlaştıran veya imkansız kılan durumu ifade etmektedir (Salvatore ve Reagle, 2002). Çoklu doğrusal bağlantının mevcut olduğu durumlarda tahmin edicide belirsizlik söz konusu olur (Greene, 2012) ve bağımlı değişkenin açıklanması güçleşir. Bu araştırmada çoklu doğrusal bağlantının bulunup bulunmadığı Varyans Artış Faktörü (VIF: Variance Inflation Factor) ile test edilmekte olup, test sonuçları Tablo 4'te sunulmaktadır. Gujarati (2004) Varyans Artış Faktörü (VIF) değerinin 10'un üzerinde olması halinde bağımsız değişkenler arasında kuvvetli ilişskinin bulunduğunu ve bunun da sorun olacağını, 10'dan küçük olması durumunda ise bu sorunun olmadığını belirtmektedir. Tablo 4'teki sonuçlar her iki modelde de (Model 2'de FDPO bağımsız değişken olarak yer almamaktadır) çoklu doğrusallığın olmadığını göstermektedir. 
Tablo 4. Çoklu Doğrusal Bağlantı Testi

\begin{tabular}{lrr}
\hline Değişkenler & $\begin{array}{r}\text { Model 1 } \\
\text { Centered VIF }\end{array}$ & $\begin{array}{r}\text { Model 2 } \\
\text { Centered VIF }\end{array}$ \\
\hline FDPO & 1.2980 & ------- \\
LNPIYD & 1.4788 & 1.2458 \\
AKO & 1.7910 & 1.7327 \\
BORC & 1.4536 & 1.4490 \\
IMT & 1.2656 & 1.2090 \\
EGKS & 1.0308 & 1.0228 \\
\hline
\end{tabular}

Panel regresyon tahmininde sabit etkiler modeli ve rassal etkiler modeli olmak üzere iki önemli yaklaşım bulunmakta olup (Baltagi, 2005; Kutlar, 2012; Tarı, 2014), bu modellerden hangisinin uygun olduğuna Hausman (1978) testi ile karar verilmektedir. Hausman testinde panel veri analizinde rassal ve sabit etkiler modelleri arasındaki en iyi tercihe, her iki model parametrelerinin bireysel etki veya gözlenemeyen etkilerle korelasyon halinde olup olmadığının belirlenmesine göre karar verilmektedir (Tarı, 2014: 484). Hausman testi hipotezleri şu şekildedir:

$\mathrm{H}_{0}$ : Rassal etkiler modeli uygundur.

$\mathrm{H}_{1}$ : Sabit etkiler modeli uygundur.

Tablo 5'te Model 1 ve Model 2 için Hausman testi sonuçları verilmektedir. Her iki modelde de $\mathrm{H}_{0}$ hipotezleri kabul edildiği için, panel veri analizi rassal etkiler modeline göre yapılacaktır.

Tablo 5. Hausman Testi Sonuçları

\begin{tabular}{lrr}
\hline & Model 1 & Model 2 \\
\hline Chi $^{2}$ Test İstatistiği & 7.32 & 1.20 \\
\hline P Olasılık Değeri & 0.1979 & 0.8781 \\
\hline
\end{tabular}

*\% 1 düzeyinde istatistiksel olarak anlaml

Panel veri analizlerine geçmeden önce modellerin yatay kesit bağımlllı̆̆ (crosssectional dependence), otokorelasyon ve değişen varyans durumlarının da tespit edilmesine ihtiyaç bulunmaktadır. Her ne kadar bazı kaynaklarda yatay kesit bağımlılığının (Baltagi, 2005; Torres-Reyna, 2007) ve otokorelasyonun (Torres-Reyna, 2007) 20-30 yılı aşan makro panellerde problem teşkil edeceği belirtilmesine karşın, bu çalışmada yatay kesit bağımlığı Pesaran (2004) testi ile, otokorelasyon ise Wooldridge (2002) testi ile araştırılmıştır. Tablo 6 'da verilen sonuçlara göre iki modelde de hem yatay kesit bağımlılığı hem de otokorelasyon problemi olduğu saptanmıştır. Ayrıca değişen varyans durumuna karşı yapılan White ve Breusch-Pagan / Cook-Weisberg testlerinde ise, modellerde değişen varyans problemi de tespit edilmiştir. $\mathrm{Bu}$ sonuçlar, modellerdeki bilgilerin tutarlı olması için dirençli standart hataların (robust standard errors) tahminini zorunlu kilmaktadır (Wooldridge, 2002). Bu yüzden bu araştırmada modeller, çeşitli çalışmalarda benzer durumlarda kullanılan (Korkmaz 
vd., 2016; Karadeniz vd., 2019) kümelenmiş dirençli robust standart hatalar kullanılarak tahmin edilmektedir.

Tablo 6. Yatay Kesit Bağımlılığı ve Otokorelasyon Testi

\begin{tabular}{lrr}
\hline & Model 1 & Model 2 \\
\hline Pesaran CD Testi (Yatay Kesit Bağımlılığı) & & \\
\hline Test İstatistiği & 4.04 & 5.83 \\
\hline P Olasılık Değeri & $0.0001^{*}$ & $0.0000^{*}$ \\
\hline Wooldridge Testi (Otokorelasyon) & & \\
\hline Test İstatistiği & 12.26 & 12.06 \\
\hline P Olasılık Değeri & $0.0013^{*}$ & $0.0015^{*}$ \\
\hline
\end{tabular}

* \% 1 düzeyinde istatistiksel olarak anlamlı

Tablo 7'de Model 1'e ait panel veri analiz sonuçları verilmektedir. Modelin bağımlı değişkeni katılım oranıdır (KTO). Hausman testi sonucunda rassal etkiler modelinin kullanması gerektiğine karar verilmiştir. F istatistiği olasılık değerinin 0,0000 çıkması modelin bir bütün olarak anlamlı olduğunu göstermektedir. Sonuçlara göre fiili dolaşım pay oranının (FDPO), yönetime katılım oranını istatistiksel olarak anlamlı olarak etkilediği saptanmıştır $(\mathrm{P}=0,0000<0,01)$. Ancak bu etki zıt yönlüdür. $\mathrm{Bu}$, halka açıklığın artmasının yönetime katılım oranını azaltması anlamına gelmektedir. Piyasa değerinin (LNPIYD) artması ise katılım oranını olumlu olarak etkilemektedir. Aktif kârlılık oranı (AKO) değişkeninin KTO ile \%5 anlamlılık düzeyinde istatistiksel olarak anlamlı ancak negatif ilişkiye sahip olduğu görülmektedir. Borç oranı ve şirket hisselerinde imtiyazlı payların bulunmasının ise KTO üzerinde anlamlı bir etkisinin olmadığı saptanmıştır. Elektronik genel kurul sisteminin varlığının (EGKS) ise KTO üzerinde pozitif ve anlamlı bir etkiye sahip olduğu görülmektedir. $\mathrm{Bu}$ sonuç genel kurula katılmayı kolaylaştıran EGKS gibi uygulamaların, yönetime katılmayı arttırdığına işaret etmektedir.

Tablo 7. Model 1 Panel Veri Analizi Sonuçları

\begin{tabular}{lrrrr}
\hline Bağımlı Değişken: KTO & & & & \\
\hline Bağımsız Değişkenler & Katsayı & Robust Std.Hata & z istatistiği & Olasılık Değeri \\
\hline FDPO & -0.7001 & 0.1254 & -5.58 & $0.0000^{* * *}$ \\
LNPIYD & 0.0223 & 0.0053 & 4.25 & $0.0000^{* * *}$ \\
AKO & -0.1179 & 0.0562 & -2.10 & $0.0360^{* *}$ \\
BORC & -0.0470 & 0.0577 & -0.82 & 0.4150 \\
IMT & -0.0006 & 0.0320 & -0.02 & 0.9860 \\
EGKS & 0.0491 & 0.0112 & 4.40 & $0.0000^{* * *}$ \\
C (Sabit) & 0.4749 & 0.1213 & 3.92 & $0.0000^{* * *}$ \\
\hline
\end{tabular}




\begin{tabular}{lc} 
Diğer İstatistikler & \\
\hline $\mathbf{R}^{2}$ & 0.5513 \\
\hline F istatistiği & 131.30 \\
\hline F istatistiği olasılık değeri & $0.0000 * * *$ \\
\hline N Gözlem sayısı & 272 \\
\hline
\end{tabular}

$*$, **, *** \% 10, \% 5 ve \% 1 düzeylerinde istatistiksel olarak anlamlı

Tablo 8'de Model 2'ye ait panel veri analizi sonuçları sunulmaktadır. Modelin bağımlı değişkeni yatırımcı katılım katsayısı (YTKK) olup, bu değişken hakim ortaklar, kontrol gücüne sahip hissedarlar veya aile üyeleri gibi ortaklar dışındaki yatırımcıların yönetime katılımlarını ölçmeyi amaçlamaktadır. Bu modele 1.Modelden farklı olarak FDPO yer almamakta, sadece finansal faktörler bağımsız değişken olarak dahil edilmektedir. Hausman testi sonucunda bu modelde de rassal etkiler modelinin kullanması gerektiği sonucuna ulaşılmıştır. Model 2'nin F istatistiği olasılık değeri, modelin bir bütün olarak anlamlı olduğunu göstermektedir $(\mathrm{P}=0,0000<0,01)$. Modelin $\mathrm{R}^{2}$ değeri $\% 22,35$ olup diğer modele göre daha düşüktür. Sonuçlara göre, piyasa değeri YTKK değişkenini pozitif ve anlamlı olarak etkilemektedir $(\mathrm{P}=0,0020<0,01)$. Aktif kârlılık (AKO), bağımlı değişkeni \% 10 anlamlılık düzeyinde anlamlı ve negatif olarak etkilemektedir. Borç oranının ilk modelde olduğu gibi bu modelde de YTKK'yi etkilemediği saptanmıştır. Benzer şekilde hisse senetlerindeki imtiyazların varlığının da yatırımcı katılımı üzerinde tesiri bulunmamaktadır. Tablo 8'den elde edilen sonuçlar, EGKS'nin yatırımcı katılım katsayısına pozitif ve anlamlı etkisinin olduğunu göstermektedir.

Tablo 8. Model 2 Panel Veri Analizi Sonuçları

\begin{tabular}{|c|c|c|c|c|}
\hline \multicolumn{5}{|l|}{ Bağımlı Değişken: YTKK } \\
\hline Değişkenler & Katsayı & Robust Std.Hata & $z$ istatistiğ $i$ & Olasılık Değeri \\
\hline LNPIYD & 0.0161 & 0.0052 & 3.08 & $0.0020 * * *$ \\
\hline AKO & -0.1053 & 0.0607 & -1.73 & $0.0830 *$ \\
\hline BORC & -0.0047 & 0.0402 & -0.12 & 0.9070 \\
\hline IMT & 0.0081 & 0.0353 & 0.23 & 0.8180 \\
\hline EGKS & 0.0525 & 0.0128 & 4.09 & $0.0000 * * *$ \\
\hline C (Sabit) & -0.3381 & 0.1006 & -3.36 & $0.0010^{* * *}$ \\
\hline \multicolumn{5}{|l|}{ Diğer İstatistikler } \\
\hline $\mathbf{R}^{2}$ & 0.2235 & & & \\
\hline $\mathbf{F}$ istatistiği & 33.08 & & & \\
\hline F istatistiği olasılık değeri & 0.0000 & & & \\
\hline N Gözlem sayısı & 272 & & & \\
\hline
\end{tabular}


Elde edilen bulguların, kurulan hipotezleri doğrulayıp doğrulamadığına ilişkin durum, Tablo 9'da özetlenmektedir. Buna göre sonuçlar bir bütün olarak incelendiğinde, borsada işlem gören hisse oranının artmasının, yatırımcıların yönetime katılmalarını zıt yönde etkilediği bulunmuştur ki (H1 hipotezi), bu sonuç teorik yaklaşımları (Karasu, 2016; Tekten, 2018) desteklemektedir. Borsadan hisse senedi alarak şirkete ortak olan yatırımcıların büyük çoğunluğunun ortaklık haklarını kullanmayı tercih etmediği Model 1'deki sonuçların yanı sıra Tablo 1'deki tanımlayıcı istatistiklerde de görülmektedir. Şirketin piyasa değerinin yüksekliğinin yatırımcıların yönetime katılmalarını etkilediği hipotezi ise hem Model 1'de hem de Model 2'de doğrulanmıştır (H2 ve H7 hipotezleri). Piyasa değeri yüksek şirketler daha yüksek işlem hacmine sahipken, aynı zamanda yatırımcılarını da genel kurullara çekebilmektedir. Araştırmada şirket kârlılı̆̆ının katılımı etkilediğine yönelik hipotezler (H3 ve H8 hipotezleri) de doğrulanmıştır, ancak etkinin yönü negatiftir. Bu sonuç, kârlılık durumu düşük şirkete yatırım yapan yatırımcıların "hesap sorma" hakkını kullanmak için genel kurullara katıldı̆̆ 1 şeklinde yorumlanabilir.

Araştırmada borç oranının şirket yönetimine katılımı etkilediğine yönelik kurulan hipotezler ise (H4 ve H9 hipotezleri) doğrulanamamıştır. Bunda borcun işletmenin sermaye yapısını oluşturan bir unsur olmasının yanında, kârlılığı arttırmak için "kaldıraç" olarak kullanılmasının ve yatırımcıların bu şekilde algılamasının da etkisi olduğu düşünülebilir. Şirket hisseleri üzerinde belirli imtiyazların bulunmasının, yönetime katılıma etkisi H5 ve H10 hipotezlerinde sınanmış, bu hipotezler de doğrulanamamıştır. Bu araştırmada genel kurullarda uzaktan katılıma izin veren elektronik genel kurul sisteminin (EGKS) varlığının yatırımcıların yönetime katılmalarına etkisi de araştırılmış, bu doğrultuda kurulan hipotezler de (H6 ve H11 hipotezleri) doğrulanmıştır. Buna göre EGKS'nin hem genel katılımı hem de hakim ortaklar dışındaki küçük yatırımcıların katılımını arttırdığı yönünde bulgulara ulaşılmıştır. Bu sonuç, Levent (2018: 100) ve Gao vd. (2019) tarafından yapılan araştırma bulgularını desteklemektedir.

Tablo 9. Hipotez Doğrulama Tablosu

\begin{tabular}{ll}
\hline Hipotezler & SONUÇ \\
\hline
\end{tabular}

H1: Şirketin fiili dolaşım pay oranı, hissedarların şirket yönetimine katılımını etkilemektedir. Doğrulandı

H2: Şirketin piyasa değeri, hissedarların şirket yönetimine katılımını etkilemektedir.

Doğrulandı

H3: Şirketin kârlılığı, hissedarların şirket yönetimine katılımını etkilemektedir.

Doğrulandı

H4: Şirketin borç oranı, hissedarların şirket yönetimine katılımını etkilemektedir.

Doğrulanamadi

H5: Şirketin hisselerinde imtiyazlar bulunması, hissedarların şirket yönetimine katılımını etkilemektedir.

Doğrulanamadı

H6: Genel kurullarda uzaktan katılıma izin veren elektronik genel kurul sisteminin varlığ hissedarların şirket yönetimine katılımını etkilemektedir.

Doğrulandı

H7: Şirketin piyasa değeri, hakim ortaklar dışındaki yatırımcıların şirket yönetimine katılımını etkilemektedir.

Doğrulandı 
H8: Şirketin kârlılığı, hakim ortaklar dışındaki yatırımcıların şirket yönetimine katılımını etkilemektedir.

Doğrulandı

H9: Şirketin borç oranı, hakim ortaklar dışındaki yatırımcıların şirket yönetimine katılımını etkilemektedir.

Doğrulanamadı

H10: Şirketin hisselerinde imtiyazlar bulunması, hakim ortaklar dışındaki yatırımcıların şirket yönetimine katılımını etkilemektedir.

Doğrulanamadı

H11: Genel kurullarda uzaktan katılıma izin veren elektronik genel kurul sisteminin varlığ1, hakim ortaklar dışındaki yatırımcıların şirket yönetimine katılımını etkilemektedir.

Doğrulandı

\section{SONUÇ VE ÖNERILER}

Bu çalışmada Borsa İstanbul'da işlem gören halka açık şirketler düzeyindeki finansal faktörlerin yatırımcıların şirket yönetimine katılımına etkisinin belirlenmesi amaçlanmıştır. $\mathrm{Bu}$ doğrultuda iki ekonometrik model kurulmuş, birinci modelde bağımlı değişken katılım oranı, ikinci modelde ise yatırımcı katılım katsayısı olarak belirlenmiş̧ir. Şirket düzeyindeki finansal faktörleri ise fiili dolaşım pay oranı, piyasa değeri, aktif kârlılık oranı, borç oranı, şirket hisselerinde imtiyazlı payların bulunma durumu ve elektronik genel kurul sisteminin varlığı temsil etmektedir. Son iki değişken ikili (binary) değişken olarak modellerde bulunmakta olup, sadece 1 ve 0 değerlerini alabilmektedir. Araştırma, Borsa İstanbul'da Metal Ana Sanayi Endeksi ve Metal Eşya Makina Endeksinde 2010-2017 yılları arasında kesintisiz olarak yer alan 34 şirketi ve 8 yıllık bir dönemi kapsamaktadır. Finansal faktörlerin etkisi hem şirket hem zaman boyutu ile ele alındığı için panel veri analizi yöntemi tercih edilmiştir. Analize geçilmeden panel veri analizi ve varsayımları ile ilgili gerekli testler yapılmıştır. $\mathrm{Bu}$ doğrultuda durağanlık, çoklu doğrusal bağlantı, otokorelasyon, yatay kesit bağımlılığı gibi analizler yapılmış, en sonunda panel veri modeli ile ilgili yapılan testler neticesinde her iki modelde rassal etkiler modelinin uygulanmasına karar verilmiştir.

Panel veri analizi bulguları, fiili dolaşımdaki pay oranının artmasının yatırımcıların genel kurula katılımını istatistiksel olarak anlamlı bir şekilde negatif etkilediğini göstermektedir. Bu sonuç literatürdeki teorik yaklaşımları (Karasu, 2016; Tekten, 2018) desteklemektedir. Özellikle Türkiye'de yatırımcılar için genel kurula iştirak etmenin, şirket yönetimine katılmanın en önemli yolu olduğu dikkate alınırsa, halka açıklığın artmasının yatırımcıların yönetime katılımlarını azalttığı sonucuna ulaşılmaktadır. Halka açıklık oranının artması ile genel kurul katılımının azalması, Yılmaz (2017) tarafindan da belirtilen yönetimde güç boşluğu ile karşılaşılma ihtimalini arttırmaktadır. Sonuçlar bu çerçevede değerlendirildiğinde, halka açıklık oranının yüksek olduğu şirketlerde, yatırımcıların genel kurul toplantılarına ilgi göstermemesi durumunda şirket yönetimlerinin azınlığın hakimiyetine girebileceği şeklinde yorumlanabilir.

Araştırmada şirketlerin piyasa değerlerinin yönetime katılmaya etkisi de incelenmiş, kurulan her iki modelde piyasa değerinin artmasının hem genel kurul katılım oranını hem de yatırımcı katılım katsayısını arttırdığı tespit edilmiştir. Buradan piyasa değeri yüksek şirketlere yatırım yapan yatırımcıların, bu şirketlerin yönetimine katılmayı daha fazla tercih ettiği sonucuna varılabilir. Piyasa değerinin yüksekliği, şirketlerin yönetim kalitesinin, kurumsallığının ve finansal performansının tek göstergesi değildir. Ancak piyasa değeri yüksek şirketlerin, daha yüksek işlem hacmine sahip olduğu ve özellikle Türkiye gibi 
gelişmekte olan ülkelerde yabancı yatırımcıların daha fazla ilgisini çektiği yönünde bir inanç bulunmaktadır. Araştırma sonuçları, bunun doğruluğunu ortaya koymamakla birlikte, piyasa değeri yüksek olan şirketlerin hisse senetlerini satın alan yatırımcıların, bu şirketlerin yönetimlerine katılmada daha istekli olduğunu göstermektedir. $\mathrm{Bu}$ açıdan, araştırma bulgularını piyasa değerinin yatırımcı profillerini etkileyebileceği şeklinde yorumlamak mümkündür.

İncelenen diğer bir finansal faktör de kârlılıktır. Araştırmada aktif kârlılık oranının da yatırımcı katılımına etkisinin bulunduğu, ancak bu etkinin beklentilerin aksine negatif olduğu saptanmıştır. Bu sonuç, kârlılık durumu düşük şirkete yatırım yapan yatırımcıların "hesap sorma" hakkını kullanmak için genel kurullara katıldığı şeklinde yorumlanabilir. Finansal faktörlerden borç oranının ise yatırımcıların yönetime katılmalarında anlamlı bir etkisinin olmadığ 1 tespit edilmiştir. Benzer şekilde şirketin hisselerinde bazı paylara imtiyazlar verilmesinin de yatırımcıların katılımını etkilemediği bulunmuştur. Düzenlemeler gereği halka açık şirketler, hisse gruplarını ve bu gruplardaki imtiyazları kamuyla paylaşmak zorundadır. Bu sonuçlara bakarak, özellikle kurumsal yatırımcıların yatırım yapmadan önce şirket hisselerindeki imtiyazları bildikleri söylenebilir.

Son olarak, genel kurullara uzaktan katılıma izin veren elektronik genel kurul sisteminin (EGKS) varlığının, hem genel kurul katılım oranını hem de hakim ortaklar dışındaki yatırımcıların şirket yönetimine katılımını istatistiksel olarak anlamlı ve pozitif etkilediği saptanmıştır. Araştırmada ortaya çıkan bu sonuç Çin'deki halka açık şirketleri inceleyen Gao vd. (2019) tarafından elde edilen bulgular ile aynı doğrultudadır. Ayrıca sonuçlar, Lattemann'ın (2005) online katılım ile ilgili beklentilerini, Karayel ve Koçak (2015) ve Levent (2018) tarafından yapılan araştırma bulgularını da desteklemektedir. Türkiye'de 2012 yılı Ekim ayından itibaren uygulamaya giren EGKS sayesinde şirket genel kurulları internetten canlı yayınlanmaktadır. Sistem, genel kurul tarihinde hisse senedini elinde bulunduran yatırımcılara sadece toplantıları izleme değil aynı zamanda yönetim kurulu ve denetçi seçme başta olmak üzere oy kullanma, toplantı esnasında görüş beyan etme ve muhalefet şerhi girme gibi imkanlar sunmaktadır. Araştırma sonuçları, sistemin varlığının şirket yönetimlerinde oluşabilecek güç boşluğunu azaltabileceği şeklinde yorumlanabilir.

$\mathrm{Bu}$ araştırma, şirket düzeyinde finansal faktörlerin yatırımcıların yönetime katılıma etkisini inceleyen Türkiye'deki ilk ampirik çalışma olma özelliğini taşımaktadır. Bu konu, uluslararası literatürde de yeteri kadar araştırılmadığı için, çalışmanın bu alanda da literatürdeki önemli bir boşluğu doldurması hedeflenmektedir.

Araştırma, literatüre yapması beklenen bu katkıların yanında şirketlere, politika yapıcılara ve düzenleyici kuruluşlara da çeşitli öneriler sunmaktadır. Bunlardan en önemlisi yatırımcıların yönetime katılmaların arttırılması gerektiğidir. Halka açık şirketlerde, hisse senedi alarak o şirketlere ortak olan yatırımcıların önemli bir kısmının şirketin nasıl yönetildiğinden çok, elde edeceği değer artışı kazancı ile ilgilendiği, bu yüzden de, şirketin yönetimine katılmadığı bir gerçektir. Bu durum, kurumsal yönetim prensiplerine uyan ve paydaşların haklarına saygı göstererek yönetilen şirket yatırımcıları için fazla bir sorun teşkil etmemektedir. Ancak bazı şirketlerde ise hakim hissedarların veya çoğunluk hisseye sahip olmamasına karşın kontrol gücünü elinde bulunduran hissedarların, şirketleri kendi şahsi çıkarları doğrultusunda yönettikleri, bunun da uzun vadede yatırımcılar aleyhinde sonuçlar doğurduğu görülmektedir. Bu açıdan şirketlere paydaş haklarına saygı göstererek ve yönetime 
katılmalarını teşvik ederek, kurumsal yönetim ilkelerini, sadece kağıt üzerinde değil uygulamaya da geçirmeleri önerilmektedir.

Şu gerçeği de vurgulamak gerekir: Borsa İstanbul'da işlem gören şirketlerin bir kısmında yatırımcıların ilgisizliği nedeniyle bazı genel kurul toplantıları çok az hissedarla yapılmakta, yeterli çoğunluk sağlanamadığı için genel kurul toplantıları ertelenebilmektedir. $\mathrm{Bu}$ çerçevede genel kurulların yatırımcıların şirket yönetimine katılabilecekleri, şirketi yönetecek kişileri seçme, onları azletme veya yönetim kuruluna aday olma, hesap sorma haklarını kullanabilecekleri en önemli organ olduğu unutulmamalıdır. Politika yapıcılara ve düzenleyici kuruluşlara, bu konuda yatırımcı bilincinin oluşturulması konusunda daha fazla çalışmalar yapmaları önerilmektedir.

Araştırma, çeşitli açılardan gelecekte bu alanda çalışacak araştırmacılar için de çeşitli öneriler sunmaktadır. Bunlardan ilki zaman boyutudur. İkinci konu ise çalışmanın kapsamı ile ilgilidir. Gelecek araştırmalar için bu araştırmadaki metodoloji takip edilerek veya geliştirilerek daha uzun bir zaman diliminde ve daha fazla şirketi kapsayan çalışmalar yapılması önerilmektedir.

\section{KAYNAKLAR}

Agarwal, Sumit - Liu, Chunlin - Rhee, S. Ghon (2008), "Investor Demand for IPOs and Aftermarket Performance: Evidence from the Hong Kong Stock Market", Journal of International Financial Markets, Institutions and Money, 18(2), pp.176-190.

Akpınar, Onur (2016), "Sermaye Yapısının Firma Performansına Etkisi: Borsa İstanbul'da Bir Uygulama", Kastamonu Üniversitesi İktisadi ve İdari Bilimler Fakültesi Dergisi, 11, ss.290-302.

Ararat, Melsa - Black, Bernard S. - Yurtoglu, B.Burcin (2017), "The Effect of Corporate Governance on Firm Value and Profitability: Time-series Evidence from Turkey", Emerging Markets Review, 30, pp.113-132.

Aytekin, Sinan - İbiş, Ayşenur (2014), "Mülkiyet Yapısının İşletmelerin Finansal Performansı Üzerindeki Etkilerinin Değerlendirilmesi: BIST Metal Eşya, Makina Endeksi (XMESY) Üzerinde Bir Uygulama", Dumlupınar Üniversitesi Sosyal Bilimler Dergisi, 40, ss.119-130.

Balasubramanian, N. - Black, Bernard S. - Khanna, Vikramaditya (2010), "The Relation between Firm-level Corporate Governance and Market Value: A Case Study of India", Emerging Markets Review, 11(4), pp.319-340.

Baltagi, Badi H. (2005), Econometric Analysis of Panel Data Third Edition, John Wiley \& Sons, England.

Bayrakdaroğlu, Ali (2010), "Mülkiyet Yapısı ve Finansal Performans: İMKB Örneği", Ekonomi Bilimler Dergisi, 2(2), ss.11-20. 
BIST (2018), "BİST Pay Endeksleri Temel Kuralları", https://www.borsaistanbul.com/docs/default-source/endeksler/bist-pay-endeksleritemel-kurallari.pdf?sfvrsn=4 ( Erişim tarihi 28.11.2019)

Black, Bernard, (2001), "The Corporate Governance Behavior and Market Value of Russian Firms", Emerging Markets Review, 2(2), pp.89-108.

Çalal, Salih (2017), "Anonim Şirketlerde İmtiyazlı Paylara Ayrıntılı Bir Bakış", Mali Çözüm Dergisi, 141, ss.161-174.

Çalışkan, M.M. Tuncer - Kerestecioğlu, Semih (2013), "Effects of Free Float Ratios on Stock Prices: An Application on ISE", Doğuş Üniversitesi Dergisi, 14(2), pp.165-174.

Dimitrov, Valentin - Jain, Prem C. (2011), "It's Showtime: Do Managers Report Better News Before Annual Shareholder Meetings?", Journal of Accounting Research, 49(5), pp.1193-1221.

Er, Bünyamin - Güneysu, Yusuf - Ergün, Tolga (2017), "Halka Arz Olan Firmaların Hisse Senedi Fiyatlarının Belirlenmesinde Kullanılan Yöntemlerin Karşılaştırmalı Analizi", Uluslararası İktisadi ve İdari İncelemeler Dergisi, 18, ss.157-166.

Gao, Huasheng - Huang, Jun - Zhang, Tianshu (2019), "Can Online Annual General Meetings Increase Shareholders' Participation in Corporate Governance?", https://papers.ssrn.com/sol3/papers.cfm?abstract_id=2689618 (Erişim tarihi 13.12.2019)

Greene, William H (2012), Econometric Analysis, Seventh Edition, Prentice Hall, Boston

Gujarati, Damodar N. (2004), Basic Econometrics Fourth Edition, McGraw-Hill, NewYork

Hausman, J.A. (1978), "Specification Tests in Econometrics", Econometrica, 46(6), pp.12511271.

James, Christopher - Edmister, Robert O. (1983), "The Relation Between Common Stock Returns Trading Activity and Market Value", The Journal of Finance, 38(4), pp.10751086.

Kandemir, Hatice Kübra (2019), "Kurumsal Yönetim ve Şeffafllğın Güçlendirilmesinde Mülkiyet Açıklama Kurallarının Rolü ve Pay Sahipliğinin Tanımlanması Sorunu", Muhasebe Bilim Dünyası Dergisi, 21(2), ss.427-453.

Karadeniz, Erdinç - Koşan, Levent - Günay, Fatih - Dalak, Selda (2019), "Otel İşletmelerinde Kârlılığı Etkileyen Değişkenlerin DuPont Analiz Tekniğiyle Ölçülmesi: Avrupa Borsalarında Ekonometrik Bir Analiz", Muhasebe ve Finansman Dergisi, 81, ss.21-36.

Karasu, Rauf (2016), "Anonim Şirketlerde Pay Sahiplerinin Yönetime Katılma Yöntemleri", Uluslararası Sosyal Araştırmalar Dergisi, 43(9), ss.1909-1916. 
Karayel, Mete - Koçak, Mehmet Alaaddin (2015), "Türkiye'de Anonim Şirketlerde Elektronik Genel Kurul Sisteminin Pay Sahiplerinin Yönetime Katılımına Etkileri: BİST 100 Şirketlerinde Bir Araştırma", KMÜ Sosyal ve Ekonomik Araştırmalar Dergisi, 17(29), ss.100-110.

Kesbiç, Cüneyt Yenal - Taşdemir, Beyza Mıynat (2019), "Halka Açıklık Oranının Finansal Performans Üzerindeki Etkisi", Yönetim ve Ekonomi: Celal Bayar Üniversitesi İktisadi ve İdari Bilimler Fakültesi Dergisi, 26(2), ss.689-703.

Kılıç, Saim - Alp, Ali - Delikanlı, İhsan Uğur (2014), "Borsa Şirketlerinde Genel Kurula Katılma ve Oy Haklarının Kullanılması: Pay Blokajı Şartının Kaldırılması Sonrasındaki Uygulama, Karşılaşılan Sorunlar ve Çözüm Önerileri", BDDK Bankacilık ve Finansal Piyasalar, 8(2), ss.75-98.

Korkmaz, Özge - Erer, Deniz - Erer, Elif (2016), "Bankacılık Sektöründe Yoğunlaşma İle Finansal Kırılganlık Arasındaki İlişki: Türkiye Örneği (2007-2014)", Muhasebe ve Finansman Dergisi, 69, ss.127-146.

Kutlar, Aziz (2012), Ekonometriye Giriş, Nobel Akademik Yayıncılık, Ankara.

Lattemann, Christoph (2005), "The Use of ICT in Annual Shareholder Meetings and Investor Relations: An Examination of the German Stock Market", Corporate Reputation Review, 8(2), pp.110-120.

Levent, Cüneyd Ebrar (2018), "Halka Açık Şirketlerin Genel Kurul Toplantılarının Elektronik Ortamda Yapılması: BİST 30 Şirketleri Üzerinde Bir Araştırma", http://www.sbe.yildiz.edu.tr/images/files/V_\%20Y\%C4\%B1ld\%C4\%B1z\%20Sosyal \%20Bilimler\%20Kongresi\%20Ozet\%20Kitab\%C4\%B1_\%20v3.pdf (Erişim tarihi 01.12.2019)

Levin, Andrew - Lin, Chien-Fu - Chu, Chia-Shang James, (2002), "Unit Root Tests in Panel Data: Asymptotic and Finite-sample Properties", Journal of Econometrics, 108(1), pp.1-24.

OECD (2004), OECD Principles of Corporate Governance, OECD Publications Service.

Pamukçu, Ayşe - Öztürk, Evren (2018), "Halka Arzlarda Düşük Fiyatlama ve Borsa İstanbul'a Arz Olma Kriterleri", Ida Academia Muhasebe ve Maliye Dergisi, 1(2), ss.21-35.

Pesaran, M. Hashem (2004), "General Diagnostic Tests for Cross Section Dependence in Panels", University of Cambridge, Faculty of Economics, Cambridge Working Papers in Economics No. 0435, pp.1-39.

Pulaşl1, Hasan (2011), "Elektronik Ortamda Anonim Şirket Genel Kuruluna İlişkin Düzenlemelerin Evrimi ve 6102 Sayılı Türk Ticaret Kanunundaki Durum", Elektronik Nehir Dergi Halil Arslanlı Bilim Arşivi, http://arslanlibilimarsivi.com/sites/default/files/makale/HasanPulasliinternetOrtamindaGenelKurul.pdf, ss.1-76 ( Erişim tarihi 15.11.2019) 
Salvatore, Dominick - Reagle, Derrick (2002), Schaum's Outline of Statistics and Econometrics, Second Edition, McGraw-Hill, New York

Strätling, Rebecca (2003), "General Meetings: A Dispensable Tool for Corporate Governance of Listed Companies?", Corporate Governance: An International Review, 11(1), pp.74-82.

Tarı, Recep (2014), Ekonometri, 10.Bask1, Umuttepe Yayınları, Kocaeli

Tatoğlu, Ferda Yerdelen (2018), Panel Zaman Serileri Analizi Stata Uygulamalı 2.Baskı, Beta Basım Yayım Dağıtım, İstanbul.

Tekten, Emel (2018), "Anonim Şirket Genel Kurul Toplantılarında Pay Sahibinin Temsilinde Güncel Gelişmeler", Erciyes Üniversitesi İktisadi ve İdari Bilimler Fakültesi Dergisi, 52, ss.279-300.

Topal, Yusuf (2006), "İMKB'ye Kayıtlı İşletmelerin Sermaye Yapıları ve Finansal Kaldıraç Oranlarının Kârlılıklarına Etkisi", Erciyes Üniversitesi İktisadi ve İdari Bilimler Fakültesi Dergisi, 27, ss.45-70.

Torres-Reyna, Oscar (2007), "Panel Data Analysis. Fixed and Random Effects using Stata (v. 4.2)", https://www.princeton.edu/ otorres/Panel101.pdf ( Erişim tarihi 08.11.2019)

TTK (2011), Türk Ticaret Kanunu 6102 sayılı.

Ünal, Oğuz Kürşat (2000), "Anonim Ortaklık Yönetim Kurulunun İmtiyazlı Hisse Senedi Çıkarma Yetkisi", Gazi Üniversitesi Hukuk Fakültesi Dergisi, 4(2), ss.1-10.

Vanlı, Veliye (2015), "Halka Açık Şirketlerde Önemli Nitelikteki İşlemler", İnönü Üniversitesi Hukuk Fakültesi Dergisi, 6(2), ss.459-472.

Wang, Maobin - Qiu, Chun - Kong, Dongmin (2011), "Corporate Social Responsibility, Investor Behaviors, and Stock Market Returns: Evidence from a Natural Experiment in China", Journal of Business Ethics, 101(1), pp.127-141.

Webb, Robert - Beck, Matthias - McKinnon, Roddy (2003), "Problems and Limitations of Institutional Investor Participation in Corporate Governance", Corporate Governance: An International Review, 11(1), pp.65-73.

Wooldridge, Jeffrey M (2002), Econometric Analysis of Cross Section and Panel Data, The MIT Press, Cambridge

Yılmaz, Özge Seçkin (2017), "Çok Ortaklı Anonim Şirketlerde Hissedarların Yönetime Tam Katılımlarının Sağlanabilmesi Amacıyla Vekaleten Oy Kullanma Sistemi'nin Güncel Yasa ve Gelişmeler Işığında Değerlendirmesi ve Bazı Öneriler", Journal of Social Policy Conferences, 73(2), ss.185-193. 